\title{
DEMOCRACY AND THE DRAMA: TOCQUEVILLE AND THE THEATRE IN AMERICA, 1831-1832
}

Fredric $M$. Litto

"If you would judge beforehand of the literature of a people that is lapsing into democracy, study its dramatic productions. The literature of the stage,. constitutes the most democratic part of their literature." This pontification, so typical of its author, Alexis de Tocqueville, may well be a key to the understanding of American cultural life during the mid-nineteenth-century period of nationalism and romanticism.

De Tocqueville, a Frenchman with an aristocratic inheritance, and a scholarly, liberal bent, came to the United States in 1831 with his friend Gustave de Beaumont to study the new American prison reforms. Their mission, an official investigation endorsed, though not paid for, by the French government, was partially in the spirit of humanitarianism of the day But it is quite clear that the two young men, de Tocqueville aged twenty-six and Beaumont twenty-nine, also had the greatest desire to visit the United States-to explore and study the fabled republic on the other side of the Atlantic. Their nine-month stay in America, from 9 May 1831 to 20 February 1832, yielded not only the promised report on the novel penitentiary systems just developed in the United States, but de Tocqueville's famed philosophical commentary on the institutions and people in a democratic state, Democracy in America(1) This work was based on observations made during the intellectual adventure which took the young Frenchmen as far west as Green Bay, as far north as Quebec, and as far south as New Orleans.

(1) - Originally published as De la Démocratie en Amérique. 2 vols. Paris: Charles Gisselin, 1835. The edition from which I quote is Democracy in $A$ merica, the Henry Reeve text, as Revised by Francis Bowen, Now Further Cor-rected and Edited with a Historical Essay, Editorial Notes, and Bibliographies by Phillips Bradley. 2 vols. New York: Vintage Books, 1960. Since the chapter on the drama is but five pages in length and my treatment of them is progressive, I have omitted citations to specific pages when quoting directly or indirectly. 
Among the people who were their informants were John Quincy Adams, Jared Sparks, Daniel Webster, Sam Houston, Charles Carrol of Carrollton, President Andrew Jackson, and Secretary of State Edward Livingston. Democracy in America was not merely a book If abstract philosophical speculations, but one of the most immediate and practical sociological analyses of a nation ever done. It is a signal of the book's worth that despite its frequent severity with certain American institutions, it was tendered admiration and gratitude by Americans since the time of its translation. In excerpted form, or in full, the Democracy has long been in use in American schools, and still today enjoys a commanding reputation among historians and social scientists.

In very brief, de Tocqueville's conclusions regarding the basic factors of the American civilization are these: their religious tradition. their mercantile bent, and the land's unlimited natural resources have made the American people "busy, moral, prosperous and contented, with a minimum of government democratically organized." (2) The obsessive concern of Americans with business-affairs, which de Tocqueville describes elsewhere in the Democracy, is a manifestation of the Protestant Ethic identified later by Max Weber and R. H. Tawney. The Calvinistic heritage of America embodied the idea that industriousness, frugality, and piety made one eligible for temporal salvation among the "elect." Frivolous activities like the theatre, which distracted believers from leading "the good life", were condemned; and consequently this religiously - oriented philosophy, so influential a factor in the creation of democracy, had a distinctive, deterministic effect on cultural matters. De Tocqueville also found the Americans, as a people, conceited and materialistic, and predicteit the influence of these aberrations on all aspects of the civilization.

It may be helpful to the reader to know that de Tocqueville was not always precise in his use of terms in the Democracy. (3) Even though it was his key word, he allowed himself to use démocratie in seven or eight different senses; and some of the quotations which follow may show this occasional ambiguity. Since this paper is not concerned with all democracies, but with American history, and since its main focus is on the drama, and not politics, the term "democracy" has been used loosely and I hope clearly. When not occurring in a quotation, "democracy" means that political-sociological condition

(2) - George Wilson Pierson, Tocqueville in America. Garden City, N.Y.: Anchor Books, 1959, p.54.

(33) - Pierson, 459. 
experienced by Americans at the time of de Tocqueville's visit (1831-1832)

Chapter XIX of Volume Two of Democracy in America is devoted to "Some observations on the Drama Among Democratic Nations." It is in this provocative analysis and prediction that one may attempt to identify the causes and effects of the drama and stage in America in the 1830's. De Tocqueville writes: since theatrical performances require no intellectual preparation or study on the part of spectators, and similarly do not allow time for the spectator to refer to his memory or to consult one more able than himself to judge for him, they are ideally suited for democratic societies, whose most salient feature is the equality of their people. Authors of literature and drama are very prompt in discovering which way the taste of the public is inclined and they shape their productions accordingly This is so because in democratic societies not only is a taste for letters introduced among the trading classes, but a trading spirit is introduced to literature-i. e., these societies are "infested with a tribe of writers who look upon letters as a mere trade." Consequently, knowing that most dramatic writers in a democracy cater to the public, look to the stage to see the disposition or attitude of that society. The corollary to this, of course, is that in the theatre "men of cultivation and of literary attainments have always had more difficulty than elsewhere in making their taste prevail over that of the people and in preventing themselves from being carried away by the latter The pit has frequently made laws for the boxes." Thus, the tyranny of the majority, de Tocqueville's great nemisis, haunts the theatre, too (4)

In point of fact, the mid-nineteenth-century was a period of excessive majority rule-in a word, an era of riots. New York saw the brutal Astor Place Riot, and the (James R.) Anderson Riots; the Boston public assaulted Edmund Kean in both 1821 and 1825, while Philadelphia witnessed the infamous MacKenzie Riot. For the most part, these disturbances were due to nationalistic feelings coming to the fore. The English dramas and English actors that had once dominated American stages were now bearing the brunt of American conceit. Native playwrights like James Nelson Barker, John Howard Payne, Mordecai Noah, Robert Montgomery Bird, John Augustus Stone and James Kirk Paulding were undeniable proof to Americans that their drama-

(4) - Although I cannot trace the original source of this fear of the "tyranny of the majority" before de Tocqueville's time, I rather doubt that it was original with him. Indeed, de Tocqueville's eminent biographer, George York: McGraw-Hill Book Company, 1961, p. p. 40, from Davis' original (Bosred Sparks (Cf. Pierson, pp. 266 and 467). 
tists had come of age. And the number and quality of American born actors had steadily increased. Edwin Forrest, James H. Hackett, Charlotte Cushman, E. L. Davenport, and Edwin Booth all made their debuts between 1820 and 1850. Though their majesties the mob might have held sway in this time, their actions were motivated by a just if overinflated pride in native accomplishments.

Again de Tocqueville writes: "Democratic communities hold erudition very cheap and care but little for what occurred at Rome and Athens; they want to hear something that concerns themselves and the delineation of the present age is what they demand." At first glance, this generalization appears to belie the facts. Can de Tocqueville so eastly overlook The Gladiator (1831!), Pelopidas (1830), Sertorius (1830), Caius Marius (1831!), Brutus (1818), The Grecian Captive (1822), Two Galley Slaves (1822), and a host of other American plays with ancient settings? What of the dozens of successful dramas with Italian Renaissance backgrounds? And what of the Indian plays, hardly a depiction of the contemporary scene for inhabitants of the Eastern seaboard in the 1830's?

The answer to this apparently gross error lies in a familiarity with the plays of the period-and not merely with their titles. The fact that foreign settings were employed by American playwrights does not mean that there was not an essentially native flavor in these plays. They had a particular relevance for a young democratic republic, and made constant reference to the political and social ideals of Americans in that day. In this sense they delineated the contemporary age most effectively (5). The Gladiator, not accidentall, was about the revolt of the slaves against their Roman masters; Pelopidas, the revolt of the Thebans against the tyranny of Sparta; Caius Marius celebrated the revolt of the Roman populace against oligarchy; Brutus, the overthrow of the Tarquins; Sertorius, the revolt of Spain against Roman rule; The Broker of Bogota and Tortesa the Usurer, the resentment of the merchant class against the oppressions of a ruling caste; Metamora, the revolt of the Indians against the encroachments of the whites; and Oralloossa, the revolt of the Indians against their Spanish conquerors. The spirit of democracy was not only on the boards when de Tocqueville visited America, it was in the air throughout the Western world. South American dominions were revolting against Spain and Portugal, and Spain itself adopted a constitution; there was a Greek Revolution in 1829, a French Revolution in 1830, and a struggle

(5) - Arthur Hobson Quinn, A History of the American Drama, from the Beginning to the Civil War. New York: Appleton-Century Crofts, Inc., 1928 , p. 267 
for freedom in Poland. Most inspiring of all, however, was the triumph of democratic institutions in America. Andrew Jackson's election to the Presidency in 1828 marked a turning point in American affairs-a veritable revolution of egalitarianism which made the common men of America conscious of their power in a democratic society.

De Tocqueville maintains that in aristocratic societies one finds that the refined tastes and arrogant bearing of the audience require the drama to depict a certain selection of human characters, certain human actions, certain virtues and certain vices. By this means the stage comes to delineate only a small part of life, frequently even representing what is not be met with in human nature at all, but rising above nature and going beyond it. No such preferences however are expressed in democratic communities. Such a public likes to see on the stage "that medley of conditions, feelings, and opinions that occurs before their eyes." The drama, thus influenced, perforce is more striking, more vulgar, and more true" In this regard and remembering that democratic citizens enjoy witnessing the representation of familiar things, one can find the background for the popularity of such native themes and characters as the Negro Minstrelsy, the Negro, the Indian, the Yankee, the Historic War, and the Frontier on the American stage of the mid-nineteenth-century (6) The figures of these dramas almost never are persons of high station, and the plots in which they are a part never center about problems like the misfortunes of a king. Instead they represent American regional types, popular conceptions of men and their foibles based on an assumption of average audience prejudice and ignorance, and worked by the playwrights into highly entertaining pieces. Jonathan, the Yankee, and the Bowery B'Hoy, as instances, were conventionalized characters who exemplified and glorified the common man and his eccentricities. Each was a contrast to the dandy, the effete cityslicker; each was a "true blue son of liberty," a figure of considerable derring-do, possessed of a strong moral strain, and known for his salty epithets or picturesque colloquial language. Epitomizations of individualism and patriotism, conceited and materialistic, these native dramatic characters of the 1820 's to 1850 's may in all justice be called American Jacksonian heroes-significant offspring of their age.

Unlike the aristicratic society which is apt to impose upon dramatic authors certain modes of expression, when democratic classes rule the stage, de Tocqueville observes, "they introduce as much licen-

(6) - These native characters are the subject of the study by Richard Moody, America Takes the Stage, Bloomington: Indiana University Press, 1955. 
se in the manner of treating subjects as in the choice of them." The reason for this is that drama is the artistic taste most natural to democratic nations, and democracies in turn encourage a decentralization which requires an ever-increasing number of dramatists, actors, and spectators to keep up with the growth of communities in every region. Thus,

such a multitude, composed of elements so different and scattered in so many different places, cannot acknowledge the same rules or submit to the same laws. No agreement is possible among ju Jges so numerous, who do not know when they may meet again, and therefore each pronounces his own separate opinion on the piece. If the effect of democracy is generally to question the authority of all literary rules and conventions, on the stage it abolishes them altogether and puts in their place nothing but the caprice of each author and each public.

Caprice: a sudden turn of mind, emotion, or action, and usually caused by a whim or impulse. Caprice signifies freedom from restraint, and is not freedom from restraint the essence of romanticism? How well suited, indeed, the romanticism of the nineteenth-century theatre was to a democratic state. The late twenties and early thirties of the century was a high watermark in romanticism: it was the era dominated by Lord Byron and the novels of Walter Scott and James Fenimore Cooper. Nathaniel Hawthorne and Edgar Allan Poe in America, and Honoré de Balzac and Prosper Mérimée in France between 1829 and 1832 were nurturing the newly-born modern romantic novel. In the theatre, the romantic revolt spurted forward with Alexandre Dumas' Henry III and Victor Hugo's Hernani in 1829 and 1830, and Robert Montgomery Bird's Pelopidas and The Gladiator in 1830-31. The dramatists of America enjoyed public license to seek out foreign plays which could be adapted for American audiences and William Dunlap and John Howard Payne led a generation of writers to sources of European influence, especially in the works of Pixérecourt, Schiller, and Kotzebue. Of partizuiar interest to Dunlap and certain others were the French mélodramesa, dramatic form that had, and continues to have, a significant influirnce upon American playwrights.

The essence of melodrama is its freedom from the observance of the strict dramatic law of cause and effect, its intensification of sentiment and exaggeration of passion. To supply the appeal which true feeling and natural motive make instantly to the audience, melodrama calls in the aid of musical accompaniment to incite emotion 
and thus weaken, even momentarily, the critical judgment and the appeal of reason (7)

Originally created in France to bring the drama closer to the people, this form of melodrama greatly attracted American theatrical managers. It not only had a universal appeal to lave, mixed audiences, but in the form of adaptations from abroad, it required no payments to be made to original authors. Moreover, American political interest in France helped prepare for mel o drama a sympathetic audience in the United States. Although American authors eventually created their own melodramatic conventions, they were heavily indebted to the French mélodrame for contributing the element of freedom of restraint which, as we have seen, so well suited their democratic condition and interest in romantic themes.

De T'ocqueville recognized that the Americans had begun to abolish the authority of earlier literary rules. His explanation of the reason for this relies upon sociological causes rather than purely aesthetic ones. He notes in reading the dramatic criticism of the time of Louis XIV that great emphasis was given to matters like the probability of the plot, character consistency and convincingness, and the propriety of the language employed by the author

It would seem that the men of the age of Louis XIV attached very exaggerated imortance to those details which may be perceived in the study, but which escape attention on the stage; for, after all, teh principal object of a dramatic piece is to be performed, and its chief merit is to affect the audience. But the audience and the readers in that age were the same: on leaving the theatre they called up the author for judgment at their own firesides.

In democracies dramatic pieces are listened to, but not read. Most of these who frequent the amusements of the stage do not go there to seek the pleasures of the mind, but the keen emotions of the heart. They do not expect to hear a fine literary work, but to see a play; and provided the author writes the language of his country correctly enough to be understood, and his characters excite curiosity and awaken sympathy, the audience are satisfied. They ask no more of fiction and immediately return to real life. Accuracy of style is therefore less required, because the attentive observance of its rules is less perceptible on the stage.

(7) - Quinn, 102 (italics mine). 
In an earlier discussion, Chapter VIII, "Literary Characteristics of Democratic Times," de Tocqueville reminds us that since the influence of the Protestant Ethic allows in a democracy to devote very little time to letters, such men seek to make best use of the whole of it . They therefore "prefer books which may be easily procured, quickly read, and which require no learned researches to be understood." Above all, "they must have what is unexpected and new Accustomed to the struggle, the crosses, and the monotony of practical life, they require strong and rapid emotions, starting passages, truths or errors brilliant enough to rouse them up and plunge them at once, as if by violence into the midst of the subject." These are the very characteristics of the romantic dramas and acting styles which dominated the stages of America when de Tocqueville visited here. He must have had the same external pressures in mind when he wrote aboute the artistic requirements of drama in a democracy:

As for the probability of the plot, it is incompatible with perpetual novelty, surprise, and rapidity of invention. It is therefore neglected, and the public excuses the neglect. You may be sure that if you succeed in bringing your audience into the presence of something that affects them, they will not care by what road you brought them there, and they will never reproach you for having excited their emotions in spite of dramatic rules.

Given these manifestations of a democratic society, the teriets of romanticism on both the real-life and artistic levels, and the reader understands the development of the melodramatic form on the American stage. Beginning with the Gothic tradition of the Kotzebue plays, introduced through the adaptations of Dunlap, the third form of drama blossomed through the nineteenth century into the scenicailygrandiose tradition of Dion Boucicault, the hairraising thrillers of Augustin Daly and Owen Davis. Would not de Tocqueville have smiled knowingly if he had been able to read Owen Davis' famed credo of the fin de siécle creators of melodrama in his autobiography, My First Fifty Years in the Theatre?

Your hero was labeled at his first entrance. Nothing was left to inference. It was almost indispensable that he knock down the first two minutes following his entrance. . Instead of having your heroine pursued by some abstract thing such as fate you had her pursued by a tangible villain bent upon cutting her throat. You piled catastrophe upon catastrophe. By the time the hero threw his protecting arms around her in the last act, she must have narrowly missed death in a train wreck and been shot at and stabbed by the villain, 
to say nothing of having passed unscathed through several conflagrations, an earthquake or two, a mine cave-in, or a magazine explosion. The play only ended when you had exhausted every possible calamity, but it ended happily: it had to end happily. And the hero remained the hero and the villain died as black as when he fist came on (8).

In the early twentieth century, such effects left the theatre in favor of the movies, for by that time they had drained for the legitimate stage every last drop of use from "perpetual novelty, surprise, and rapidity of invention."

Despite his conclusion that the drama is the pastime best suited for democratic communities, de Tocqueville is forced to admit that very few people in the United States as of that time went to the theatre. They indulged in theatrical amusement only with the greatest reserve for several reasons, he observed. As cultural descendants of the Puritans, Americans have been deeply influenced in regard to scenic performances. The Puritans were enemies to amusements and reserved a special abhorrance for the stage because of the traditional Judeo-Christian fear of representing graven images, and because of the somewhat sullied moral reputation of theatrical people since Roman times. Further, "the extreme regularity of habits and the great strictness of morals that are observable in the United States have as yet," de Tocqueville remarked, "little favored the growth of dramatic art. .People who spend every day in the week in making money, and Sunday in going to church, have nothing to invite the Muse of Comedy." It is actually remarkable how integral a part of the main theme of Democracy in America this analysis. Yet the reader wonders whether the interpretation was developed as the result of empiric evidence, or whether it arose from a need to retain unity within the work. As yet no study has been done on the attendance records of pre-Civil War theatres in America, and so the reader's doubts cannot soon be assuaged.

De Tocqueville adds:

A single fact suffices to show that the stage is not very popular in the United States. The Americans, whose laws allow of the utmost freedom, and even license of language in all other respects, have

(8) - Quoted in Jordan Y Miller, American Dramatic Literature, New York: McGraw-Hill Book Company, 1961, p. 40, from Davis' original (Boston, 1950). 
nevertheless subjected their dramatic authors to a sort of censorship. Theatrical performances can take place only by permission of the municipal authorities. This may serve to show how much communities are like individuals; they surrender themselves unscrupulously to their ruling passions and afterwards take the greatest care not to yield too much to the venemence of tastes that they do not possess.

Although theatrical activities did not begin on the professional level until quite late in the colonial period, the generation which remembered plays disguised as "moral dialogues" saw the last major opposition stronghold, the city of Boston, relent and permit a playhouse to be built in 1794. To what extent censorship of the stage was a common or infrequent phenomenon in the middle of the nineteenth-century remains a subject for further investigation.

This leaves us, then, with de Tocqueville's last observation-prediction in the chapter on drama. He reminds us again that "no portion of literature is connected by closer or more numerous ties with the present condition of society than the drama." But, he maintains, in a democracy the dramatic authors of the past live only in books, "for pieces written for a different public will not attract an audience." "The drama of one period," he declares, "can never be suited to the following age if in the interval an important revolution has affected the manners and laws of the nation." It is at first a simple matter to say that de Tocqueville is rather off the mark here, for the managers of the American theatres depended upon the classics of English drama to pull them out of difficult financial binds, and their records show Shakespeare, Sheridan, Otway, Farquhar, Goldsmith, and Kotzebue on the boards long after de Tocqueville returned to France. Indeed, even when de Tocqueville was in New York through the month of June, 1831, the Bowery Theatre, long known as the playhouse of the unrefined classes of New York, played more than a week of Shakespeare: Richard III on the 13th, Hamlet on the 14th, Julius Caesar on the 16th, Henry IV on the 20th and the Merchant of Venice on the 23rd. But de Tocqueville, we must remember, was predicting the effects of democracy in the long run. And his closing sentence in the chapter forces us to reexamine more recent theatre history, where we discover that his quasi-philosophical, quasi-sociological prognostication has indeed come to pass. "The traditional taste of certain individuals, vanity, fashion, or the genius of an actor may sustain or resuscitate for a time the aristocratic drama among a democracy; but it will speedily fall away of itself, not overthrown, but abandoned." And we turn to our present day and seek the whereabouts of the dra- 
mas of past ages. They are in books, and they are on academic stages, and they make a sometimes impressive appearance in professional playhouses when there is an especially prominent actor or actress in the leading role and offering a tour de force. De Tocqueville, in the final analysis, is again correct.

In comparing de Tocqueville with other foreign observers of the American theatre during the mid-nineteenth century, some interesting facts come to light. (9) Almost all English travellers visiting America visited the same cities as did two young Frenchmen, de Tocqueville and Beaumont: New York, Philadelphia, Baltimore, Washington, Charleston, New Orleans, and Cincinnati. The rest of the country went unknown to the Englishmen. Although the two Frenchmen saw no small part of the frontier in Michigan and Wisconsin. Neither Frenchmen nor Englishmen gave, in their accounts published later. details of the interiors of homes, theatres, descriptions of common appliances, or informative statistics. It was only the curiosities which attracted their attention, and on the rare occasions when they cited references for their information, the authority of such references was questionable. Most Englishmen were surprised by the good behavior of American audiences in the theatres, and a few noted with real astonishment the scarcity of women in the audiences. It was the Englishmen who again observed that American performances were well attended by attentive and intelligent audiences, although they did not believe the spectators suitably dressed for theatre-going. They proudly reported, as de Tocqueville carefully did not, that the American thatre was truly a derivative one, dependent upon the English stage for many actors, most dramatic forms, numberless themes, and basic staging techniques. Indeed, it was one of de Tocqueville's greatest failings in the Democracy that he never fully grasped the significance of America's English heritage. He made a picture that actually had depth into an ideal image, one flattened out and without sufficient perspective. (10) His approach to the study of American institutions was excessively a priori, and his tendency, in general, was to oversimplify, to explain too much by little. One can find only two entries in his journals testifying to his visits to American theatres (14 October, in Philadelphia, and 1 January, in New Orleans) At home in France he had but to glance through these journals, and letters he had written to his family at home as a record of his American expe-

(9) - All of mv information on English travellers comes from Jane L. Mesick, The English Traveller in America, New York, 1922, pp. 230235, and 336-345. (10) - Pierson, 466 . 
riences, in order to evaluate the institutional practices of an incipient democracy De Tocqueville, after his nine month stay, thought he knew where the weaknesses of democracy lay. His writings make plain that he was not a tourist or visitor in the customary sense of those words. He omitted detailed description because he was interested in essences - in the "real" character of democratic people - the "inward qualities of the race." De Tocqueville was interested in the theatre, as with everything else in America, as a symbol of equality. The materialism, the conceit, the moralistic and tyrannical elements attendant upon societies of so-called equality he also found in the theatre and drama of the mid-century period.

Perceptive and intellectually ambitious, de Tocqueville is important to us today as one who was a foreseer. At times his observations and conclusions were not quite right; but these reservations notwithstanding, I believe that the close reading of his work by the student of American dramatic history will be both provocative and enlightening.

\section{BIBLIOGRAFIA}

Broderson, Arvid. "Themes in the Interpretation of America by Prominent Visitors from Abroad", Annals of the American Academy of Political and Social Science, CCVC (September, 1954), 22-26.

Brown, $\mathrm{T}$ Allston. A History of the New York Stage, from the First Performance in 1732 to 1901. 3 vols. New York: Dodd, Mead and Company, 1903.

"The Error of de Tocqueville," The North American Review, CII (1866), 321.

Freedley, George and John A. Reeves. A History of the Theatre. 2 ed. New York: Crown Publishers, 1941.

Gargan, Edward T "Some Problems in Tocqueville Scholarship", Mid-America, XLI (January, 1959), 3-26.

Hartnoll, Phyllis. The Oxford Companion to the Theatre. 2 ed. London: Oxford University Press, 1957.

Hewitt, Barnard. Theatre U.S.A., 1668 to 1957. New York: McGraw-Hill, 1959.

Hughes, Gleni. A History of the American Theaatre, 1700-1950. New York: French, 1951.

James, Reese D. Old Drury of Philadelphia, A History of the Philadelphia Stage, 1800-1835. Philadelphia: University of Pennsylvania Press, 1932.

Marshall, Margaret. "Notes by the Way (Alexis de Tocqueville's Discussion of Cuktural Matters," Nation, CLXII (February 2, 1946), 170-72.

Mayer, J. P. "Toqueville's Travel Diaries, "Encounter, LIV (March, 1958), 54-60. 
Messick, Jane L. The English Traveller in America. New York, 1922.

Miller, Jordan Y American Dramatic Literature. New York: McGraw-Hill, 1961 .

Moody, Richard. America Takes the Stage, Romanticism in American Drama and Theatre, 1750-1900. Bloomington, Ind.: Indiana University Press, 1965.

- The Astor Place Riot. Bloomington, Ind.: Indiana University Press, 1958.

Pierson, George Wilson. Tocqueville in America. Garden City, N.Y.: Anchor, 1959.

Quinn, Arthur Hobson. A History of the American Drama, From the Beginning to the Civil War. New York: Appleton-Century-Crofts, 1928.

Read, Herbert. "De Tocqueville on Art in America," Adelphi, XXIII (OctoberDecember, 1946), 9-13.

Tocqueville, Alexis de. Democracy in America. The Henry Reeve Text, as Revised by Francis Bowen. 2 vols. New York: Vintage Books, 1960. Journey to America. New Haven: Yale University Press, 1960. 